\title{
ANALISA REKAYASA NILAI DESAIN STRUKTUR SARUNG UNTUK MEMENUHI SELERA KONSUMEN
}

\author{
${ }^{1}$ Kiswandono, ${ }^{2}$ Sony Hariyanto \\ ${ }^{1}$ Prodi Teknik Industri, Fakultas Teknologi Industri, Institut Teknologi Nasional Malang \\ ${ }^{2}$ Prodi Teknik Informatika, Fakultas Teknologi Industri, Institut Teknologi Nasional Malang \\ 123kiswandono@gmail.com
}

\begin{abstract}
Abstrak. Dalam meningkatkan mutu hasil produksi kain tenun banyak faktor yang harus di perhatikan agara mempunya kualitas yang baik. Begitu pula hal nya dengan kain sarung selain motif nya desain struktur yang di utamakan, faktor yang harus di perhatikan adalah karakteristik,pemilihan model dan ukuran, mengingat tingkat selera konsumen berbeda-beda. Selera identik dengan keinginan adalah hasrat akan pemuas tertentu dari kebutuhan tersebut.

Rekayasa nilai adalah suatu teknik atau metode pengendalian biaya dengan menganalisa nilai terhadap fungsi nya dengan kata lain rekayasa nilai bermaksud menghasilkan suatu yang optimalbagi sejumlah uang yang di keluarkan. Penerapan rekayasa nilai adalah suatu untuk menyelesaikan masalah. Tahap - tahap yang di lakukan dalam rencana kerja penerapan metoder rekayasa nilai terdiri dari 5 tahap yaitu : tahap informasi,tahap kreatif,tahap analisa,tahap pengembangan, dan tahap presentasi. Berdasarkan hasil analisa dan perhitungan yang di lakukan dengan rekayasa nilai di peroleh 3 alternastif : harga, model,kombinasi warna, estetika dan kualitas bahan. Adapun hasil analisa alternatif desain produk sarung tenun adalah alternatif desain awal yang mempunyai performance terbesar yang di pertimbangkan untuk di produksi dalam jumlah yang besar dengan biaya bahan dan harga jual produk adalah Rp 151.800
\end{abstract}

Kata kunci : Rekayasa nilai, desain struktur kain sarung, selera konsumen

\section{Pendahuluan}

Tanpa disadari kita lupa akan keanekaragaman budaya Indonesia yang juga terdapat di dunia tekstil dimana dari berbagai macam daerah terdapat produk tekstil yang dihasilkan yang masih menggunakan peralatan sederhana seperti contoh kain sarung.

Dengan banyaknya persaingan, kita harus memberikan perhatian khusus terhadap produk yang dihasilkan dari segi kualitas maupun motif desain yang ditawarkan. Hal ini juga ditunjang dengan adanya promosi pada produk yang dihasilkan sehingga lebih dikenal oleh konsumen dan bisa bersaing di pasaran. Dimana persaingan antara harga dan desain sarung tenun yang ada di pasaran sangatlah bervariasi.

Dengan adanya persaingan yang terjadi membuat kita harus lebih memperhatikan keinginan pasar dan untuk meningkatkan nilai tambah bagi para pengrajin kain adatmencoba menerapkan rekayasa nilai pada desain sarung tenun dengan alternatif lain yang memungkinkan untuk memenuhi permintaan pasar dengan selera konsumen dengan harga dan mutu / kualitas yang baik sehingga lebih diminati oleh seluruh kalangan baik muda maupun tua.

Sebuah industri untuk bisa memenangkan persaingan dalam rangka merebut pangsa pasar yang ada, adalah bagaimana bisa selalu menarik minat konsumen dengan produk-produk baru yang sesuai dengan tuntutan jaman.

\section{Landasan Teori}

Saat itu perusahaan General Electric menghadapi kekurangan material dan tenaga kerja untuk memproduksi komponen-komponen persenjataan pesawat terbang. Value Engineering pertama kali dilakukan oleh Lawrence D. Miles yang kemudian dikenal sebagai bapak Value Engineering. Ia ditugaskan pada bagian pengadaan bahan baku pada General Electric Company, yang pada saat itu sibuk membuat perlengkapan perang yang membutuhkan bahan baku yang sulit dicari. Miles mengembangkan beberapa pemecahan, menguji dan menerapkan pada proses produksi berdasarkan konsep fungsional yang ternyata membawa hasil baik. 
Sejak saat itu lahirlah konsep fungsional yang merupakan suatu pendekatan untuk memecahkan berbagai maalah. Pendekatan fungsional ini merupakan kunci keberhasilan Miles dalam melaksanakan tugasnya dan merupakan sesuatu hal yang menjadi dasar dari teknik yang dikembangkannya.

Setelah Analisis Nilai ini dimulai dikenal manfaatnya maka mulailah dipakai untuk berbagai kegiatan produksi yang lain. Semenjak saat itu sistem tersebut dikenal dengan nama Rekayasa Nilai (Value Engineering).

Rekayasa nilai adalah suatu teknik yang mengidentifikasikan fungsi-fungsi yang diinginkan dan menetapkan nilai-nilainya mengembangkan alternatif-alternatif untuk memenuhi fungsi-fungsi tersebut dengan biaya yang minimum. Karakteristik Rekayasa Nilai adalah:

a. Berorientasi pada sistem untuk menentukan dan menghilangkan biaya yang tidak diperlukan dengan cara mengidentifikasikan biaya tersebut.

b. Memakai pendekatan multidisiplin, yaitu suatu kelompok yang terdiri dari sejumlah ahli dari berbagai disiplin ilmu serta konsultan rekayasa nilai.

c. Berorientasi pada siklus hidup, utnuk meneliti jumlah biaya yang dikeluarkan untuk memperoleh dan mengoperasikan fasilitas yang diperlukan.

d. Suatu teknik manajemen yang telah terbukti keberhaslannya.

e. Berorientasi pada fungsi, untuk mencapai fungsi yang diperlukan sesuai dengan nilai yang diperoleh.

f. Pola kreatif proses perancangan harus dapat mengidentifikasikan alternatifalternatif pemecahan masalah secara kreatif.

Rekayasa nilai bukan suatu proses pengurangan biaya dengan jalan menekan biaya desain dan mengurangi biaya kualitas, keadaan serta penampilannya tetapi hasil-hasil yang dicapai dalam rekayasa nilai dapat berupa alternatif, penggunaan bahan, desain baru dan sebagainya dengan pertimbangan alternatif atau desain tersebut memiliki nilai yang lebih baik.

\section{Prinsip Dasar Rekayasa Nilai}

Tujuan rekayasa nilai adalah mendapatkan nilai (value) semaksimal mungkin, secara sederhana value dapat dinyatakan sebagai berikut:

$V \max =\frac{F}{\mathrm{Cmin}}$

Dimana : $V_{\max }=$ nilai maksimal, $C_{\min }=$ biaya minimal, dan $\mathrm{F}=$ Fungsi. Fungsi disini bisa juga dinyatakan dengan kata benda dan kata sifat, jadi untuk nilai $\mathrm{V}$ bisa juga dinyatakan sebagai berikut:

$$
V=\frac{\text { Performance }}{\text { Biaya }}
$$

Dimana :

Performance : Keuntungan atau manfaat yuang diperoleh dari fungsi-sungsi suatu produk. Nilai (value) dapat dirumuskan sebagai rasio antara performance yang ditampilkan oleh suatu fungsi terhadap biaya yang dikeluarkan untuk mendapatkan fungsi tersebut. Persamaan tersebut menunjukkan ukuran dari suatu keberhasilan dalam desain. Nilai dinyatakan sebagai perbandingan antara performansi yang diberikan oleh sistem yang sedang didesain dengan jumlah biaya untuk mengadakan fungsi-fungsi yang diberikan oleh desain. 
Hasil Penelitian dan Pembahasan

Tabel Susunan bobot penilaian responden

\begin{tabular}{|c|c|c|c|c|}
\hline \multirow[t]{2}{*}{ No } & \multicolumn{4}{|c|}{ Adjective } \\
\hline & 1 & 2 & 3 & 4 \\
\hline 1 & 40 & 10 & 10 & 40 \\
\hline 2 & 20 & 30 & 30 & 20 \\
\hline 3 & 30 & 40 & 20 & 10 \\
\hline 4 & 20 & 40 & 10 & 30 \\
\hline 5 & 30 & 30 & 20 & 20 \\
\hline 6 & 10 & 40 & 10 & 40 \\
\hline 7 & 30 & 10 & 40 & 20 \\
\hline 8 & 10 & 20 & 30 & 40 \\
\hline 9 & 20 & 20 & 30 & 30 \\
\hline 10 & 40 & 10 & 10 & 40 \\
\hline 11 & 30 & 20 & 20 & 30 \\
\hline 12 & 20 & 20 & 30 & 30 \\
\hline 13 & 20 & 30 & 20 & 30 \\
\hline 14 & 20 & 20 & 20 & 40 \\
\hline 15 & 40 & 40 & 10 & 10 \\
\hline 16 & 40 & 30 & 20 & 10 \\
\hline 17 & 30 & 10 & 20 & 40 \\
\hline 18 & 40 & 20 & 10 & 30 \\
\hline 19 & 40 & 30 & 20 & 10 \\
\hline 20 & 30 & 10 & 20 & 40 \\
\hline 21 & 40 & 20 & 10 & 30 \\
\hline 22 & 30 & 20 & 20 & 30 \\
\hline 23 & 20 & 30 & 10 & 40 \\
\hline 24 & 30 & 20 & 20 & 30 \\
\hline 25 & 40 & 10 & 10 & 40 \\
\hline 26 & 30 & 10 & 20 & 40 \\
\hline 27 & 30 & 20 & 10 & 40 \\
\hline 28 & 40 & 10 & 10 & 40 \\
\hline 29 & 20 & 40 & 20 & 20 \\
\hline 30 & 40 & 10 & 10 & 40 \\
\hline 31 & 10 & 20 & 30 & 40 \\
\hline 32 & 20 & 20 & 30 & 30 \\
\hline 33 & 20 & 30 & 10 & 40 \\
\hline 34 & 30 & 10 & 40 & 20 \\
\hline 35 & 10 & 20 & 30 & 40 \\
\hline 36 & 20 & 20 & 30 & 30 \\
\hline 37 & 30 & 20 & 10 & 40 \\
\hline 38 & 20 & 30 & 10 & 40 \\
\hline
\end{tabular}

\begin{tabular}{|l|l|l|l|l|}
\hline 39 & 20 & 10 & 30 & 40 \\
\hline 40 & 10 & 10 & 40 & 40 \\
\hline 41 & 20 & 40 & 20 & 20 \\
\hline 42 & 30 & 20 & 10 & 40 \\
\hline 43 & 20 & 20 & 20 & 40 \\
\hline 44 & 40 & 10 & 20 & 30 \\
\hline 45 & 10 & 20 & 30 & 40 \\
\hline 46 & 20 & 20 & 30 & 30 \\
\hline 47 & 40 & 10 & 10 & 40 \\
\hline 48 & 30 & 20 & 20 & 30 \\
\hline 49 & 20 & 20 & 30 & 30 \\
\hline 50 & 20 & 30 & 20 & 30 \\
\hline$\sum X$ & 1120 & 1070 & 1010 & 1600 \\
\hline & 22,4 & 21,4 & 20,4 & 32 \\
\hline Rank & 2 & 3 & 4 & 1 \\
\hline
\end{tabular}




\section{Pembahasan}

Setelah melihat hasil grafik dari desain awal prdouk sarung tenun untuk kriteria yang bernilai negatif yaitu untuk kriteria model kombinasi warna menarik, maka perlu di tambah atau di naikkan untuk memperoleh produk yang ideal. Hal ini ternyata di pengaruhi oleh estetika dan kualitas bahan yang terkait. Kedua kriteria diatas di pengaruhi oleh estetika dan kualitas bahan.

\section{Identifikasi dan analisa fungsi}

Untuk fungsi utama dan pendukung dari desain sarung tenun di tunjukkan dengan model penjelasan seperti berikut :

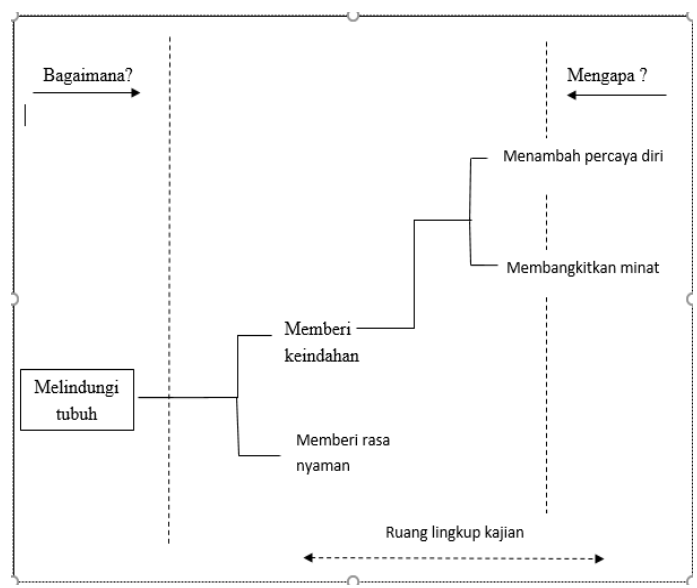

Gambar Analisa fungsi sarung tenun

\section{Harga}

Tabel 1 Zero-One untuk harga

\begin{tabular}{|c|c|c|c|c|c|c|}
\hline Alternatif & 1 & 2 & 3 & 4 & Jumlah & index \\
\hline 1 & 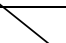 & 1 & 1 & 1 & 3 & $3 / 7$ \\
\hline 2 & 0 & & $1 / 2$ & 1 & $11 / 2$ & $\begin{array}{l}1 / 2 \\
/ 7\end{array}$ \\
\hline 3 & 0 & 1 & 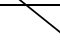 & 0 & 1 & $1 / 7$ \\
\hline 4 & $1 / 2$ & 1 & $1 / 2$ & 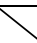 & 2 & $1 / 7$ \\
\hline & \multicolumn{4}{|c|}{ Total } & \multicolumn{2}{|l|}{7} \\
\hline
\end{tabular}

\section{Model Kombinasi Warna Menarik}

Tabel 2 Zero-One untuk model Kombinasi Warna Menarik

\begin{tabular}{|c|c|c|c|c|c|c|}
\hline Alternatif & 1 & 2 & 3 & 4 & Jumlah & index \\
\hline 1 & 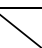 & 1 & 0 & 1 & 2 & $2 / 7$ \\
\hline 2 & $1 / 2$ & 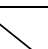 & 0 & 1 & $1 \frac{1}{2}$ & $3 / 7$ \\
\hline 3 & 0 & $1 / 2$ & 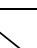 & 1 & $11 / 2$ & $1 / 7$ \\
\hline 4 & 0 & 1 & 1 & & 2 & $1 / 7$ \\
\hline \multicolumn{5}{|c|}{ Total } & \multicolumn{2}{|l|}{7} \\
\hline
\end{tabular}

Tabel 3 Zero-One untuk Estetika

\begin{tabular}{|c|l|l|l|l|l|l|}
\hline Alternatif & 1 & 2 & 3 & 4 & Jumlah & index \\
\hline 1 & & 0 & 1 & 1 & 2 & $2 / 7$ \\
\hline 2 & 1 & & 1 & 1 & 3 & $3 / 7$ \\
\hline 3 & 0 & 0 & & 1 & 1 & $1 / 7$ \\
\hline 4 & 0 & 1 & 0 & & 1 & $1 / 7$ \\
\hline \multicolumn{7}{|c|}{ Total } \\
\hline \multicolumn{7}{|c|}{} \\
\hline
\end{tabular}

\section{Kualitas Bahan}

Tabel 4 Zero-One untuk Kualitas bahan

\begin{tabular}{|c|l|l|l|l|l|l|}
\hline $\begin{array}{c}\text { Altern } \\
\text { atif }\end{array}$ & 1 & 2 & 3 & 4 & $\begin{array}{l}\text { Jumla } \\
\mathrm{h}\end{array}$ & index \\
\hline 1 & & 1 & 1 & $1 / 2$ & $2 \frac{1 / 2}{2}$ & $3 / 7$ \\
\hline 2 & 0 & & $1 / 2$ & 0 & $1 / 2$ & $1 \frac{1 / 2}{2} 7$ \\
\hline 3 & 0 & $1 / 2$ & 1 & $1 \frac{1 / 2}{2}$ & $1 / 7$ \\
\hline 4 & $1 / 2$ & 1 & 1 & & $21 / 2$ & $1 / 7$ \\
\hline \multicolumn{5}{|c|}{ Total } & 7 & 7 \\
\hline
\end{tabular}

\section{Matriks Evaluasi}

Hasil dari matriks evaluasi dapat di lihat pada tabel di bawah ini

Tabel 5 Matriks Evaluasi

\begin{tabular}{|c|c|c|c|c|c|c|}
\hline $\mathrm{N}$ & Altern & \multicolumn{4}{|c|}{ Adjective } & \multirow[t]{3}{*}{ total } \\
\hline $\mathrm{O}$ & & 1 & 2 & 3 & 4 & \\
\hline & Bobot & 1 & 3 & 4 & 2 & \\
\hline \multirow[t]{2}{*}{1} & \multirow[t]{2}{*}{ A-1-X4 } & $3 / 7$ & $11 / 2 / 7$ & $1 / 7$ & $1 / 7$ & \multirow[t]{2}{*}{0,997} \\
\hline & & 0,428 & 0,214 & 0,142 & 0,142 & \\
\hline \multirow[t]{2}{*}{2} & \multirow[t]{2}{*}{ B-1-Y2 } & $2 / 7$ & $11 / 2 / 7$ & $11 / 2 / 7$ & $2 / 7$ & \multirow[t]{2}{*}{0,998} \\
\hline & & 0,285 & 0,214 & 0,214 & 0,285 & \\
\hline \multirow[t]{2}{*}{3} & \multirow[t]{2}{*}{ C-1-Z4 } & $2 / 7$ & $3 / 7$ & $1 / 7$ & $1 / 7$ & \multirow[t]{2}{*}{0,997} \\
\hline & & 0,285 & 0,428 & 0,142 & 0,142 & \\
\hline \multirow[t]{2}{*}{4} & \multirow{2}{*}{$\begin{array}{l}\text { Desain } \\
\text { Awal }\end{array}$} & $21 / 2 / 7$ & $1 / 2 / 7$ & $11 / 2 / 7$ & $21 / 2 / 7$ & \multirow[t]{2}{*}{0,999} \\
\hline & & 0,357 & 0,071 & 0,214 & 0,357 & \\
\hline
\end{tabular}

\section{Kesimpulan}

Setelah dilakukan metode rekayasa nilai pada desain sarung tenun yang dapat diambil kesimpulan sebagai berikut :

1. Informasi yang di dapat dari hasil survey, wawancara, dan kuisoner, yang di sebarkan pada responden adalah :

A. Data tentang material dari sarung tenun

B. Kriteria/adjective dari sarung tenun tentang harga,model kobinasi warna estetika, dan kualitas bahan

2. Setelah di lakukan analisa morfologis dan penyebaran kuisoner tentang pemilihan alternatif desain. Hasil

\section{Estetika}


analisa morfologis di dapat 3 alternatif desain sarung tenun, yaitu :
A. Alternatif A-1-X4
B. Alternatif B-1-Y2
C. Alternatif $\mathrm{C}-1-\mathrm{Z} 4$

3. Kondisi usulan dari desain awal memiliki performance dan nilai baik, yaitu :

A. Kondisi awal : performance $=$ 0,999 , nilai $=1,34$

B. Kondisi usulan: performance $=0,997$, nilai $=1,44$

4. Dari perhitungan matriks zero-one yang kemudian di lanjutkan dengan matriks evaluasi di dapat performance alternatif desain dengan ranking terebsar sebagai berikut:
A. Alternatif A-1-X4 dengan performance 0,997
B. Alternatif B-1-Y2 dengan performance 0,998
C. Alternatif C-1-Z4 dengan performance 0,997

5. Perhitungan biaya bahan dan harga jual produk terpilih dan dari desain awal harga jual per sarung adalah Rp. 151.800

\section{DAFTAR PUSTAKA}

[1] Arikunto,Suharsimi. "Prosedur Penelitian", Edisi Revisi V,Rineka Cipta,2002

[2] Heller, Edward, D. " Value Management, Value Engineering and Cost Reduction", Advision- WesleyPublishiung Company.

[3] Jumaeri, et al, Textile Design, Institut Teknologi Tesktil,Bandung,2001

[4] Kotler, Philip, "Manajemen Pemasaran", Edisi 8, Salemba Empat,2001

[5] Kusnadi, H., Marwan \& Kadarisman Sumeidi, H. Pengantar Bisnis dan Wirausaha,Universitas Brawaijaya Malang,2001

[6] Mitchel, Robert. "The Application of Value Engineering And Analysis in Design and Construction", Jakarta, 2000

[7] Pedoman Penulisan Karya Ilmiah, Edisi Keempat, Universitas Negeri Malang (UM),2000

[8] Soeharto, Imam, "Manajemen Proyek", Erlangga Jakarta,2000 